\title{
践 New Disease Reports \\ First report of Columnea latent viroid (CLVd)in Gloxinia gymnostoma, G. nematanthodes and G. purpurascens in a botanical garden in Denmark
}

\author{
S.L. Nielsen* and M. Nicolaisen
}

Aarhus University, Department of Integrated Pest Management, Forsøgsvej 1, 4200 Slagelse, Denmark

*E-mail: steenl.nielsen@agrsci.dk

Received: 28 May 2010. Published: 21 Jul 2010.

In 2009, a survey for pospiviroids in ornamental plants from the families Gesneriaceae and Solanaceae, conducted in the glasshouses of the Botanical Garden of Aarhus, identified Columnea latent viroid in Gloxinia gymnostoma, G. nematanthodes and G. purpurascens.

RNA was extracted from $100 \mathrm{mg}$ fresh leaf material using the RNeasy Plant Mini Kit (Qiagen). RT-PCR was carried out using the Vid primers of Verhoeven et al. (2004) and the pCLVd4 and pCLVdR4 primers of Spieker (1996) with the OneStep RT-PCR Kit (Qiagen). An isolate of CLVd (9389007481), kindly provided by J.Th.J. Verhoeven, was used as positive control. A product of the expected size (c. $350 \mathrm{bp}$ ) was obtained from all three Gloxinia species and was subsequently sequenced. A BLAST search in the NCBI GenBank confirmed all three samples to be CLVd. However, as the sequences indicated presence of more than one genotype in the three Gloxinia species, the PCR products were cloned using the Stratagene ${ }^{\mathrm{TM}}$ PCR Cloning Kit. Four clones from each Gloxinia species were sequenced and compared by alignment. A few nucleotide differences were observed in the CLVd sequences within and between hosts. The CLVd sequences have the following GenBank Accession Nos: G. purpurascens, HM043810 to HM0438113; G. gymnostoma, HM043814 to HM043816; and G. nematanthodes, HM043817 to HM043820.

This is the first record of Gloxinia species being hosts of CLVd. CLVd has previously been found in ornamentals Columnea erythrophae (Hammond et al., 1989), Nemathanthus wettsteini (Singh et al., 1992) and Brunfelsia undulate (Spieker, 1996), and in tomato (Verhoeven et al., 2004; Steyer at al. 2009; Nixon at al., 2009). The three Gloxinia species originate from South America, and G. nematanthodes and G. purpurascens more specifically from Bolivia. The plants came to the Botanical Garden of Aarhus in 1987/88 from a plant collection in USA. The three Gloxinia species stood close to each other in the glasshouse of the Botanical Garden of Aarhus. No other pospiviroids were detected in the nine other gesneriaceous and three solanaceous species in the same glasshouse, or in 110 more plants of the two families from neighbouring glasshouses, using the Vid and Posp1 primers of Verhoeven et al. (2004). This suggests that the viroid infection originated from the host plants' place of origin

\section{Acknowledgements}

The authors would like to thank Mr Bent Lorenzen and Mr Jan Rasmussen for admittance to and assistance in the Botanical Garden of Aarhus. The activities were part of a project initiated by the EU ERA-network EUPHRESCO.

\section{References}

Hammond R, Smith DR, Diener TO, 1989. Nucleotide sequence and proposed secondary structure of Columnea latent viroid: a natural mosaic of viroid sequences. Nucleic Acids Research 17, 10083-10094. [doi:10.1093/nar/17.23.10083]

NixonT, Glover R, Mathews-Berry S, Daly M, Hobden E, Lambourne C, Harju V, Skelton A, 2009. Columnea latent viroid (CLVd) in tomato: the first report in the United Kingdom. New Disease Reports (2009) 19, 30.

Singh RP, Lakshman DK, Boucher A, Tavantzis SM, 1992. A viroid from Nematanthus wettsteinii plants closely related to the Columnea latent viroid. Journal of General Virology 73, 2769-2774 [doi:10.1099/0022-1317-73-11-2769]

Spieker RL, 1996. A viroid from Brunfelsia undulate closely related to the Columnea latent viroid. Archives of Virology 141, 1823-1832. [doi:10.1007/BF01718197]

Steyer S, Olivier T, Skelton A, Nixon T, Hobden E, 2009. Columnea latent viroid (CLVd): first report in tomato in France. New Disease Reports (2009) $20,4$.

Verhoeven JTh.J, Jansen CCC, Willemen TM, Kox LFF, Owens RA, Roenhorst JW, 2004.Natural infections of tomato by Citrus exocortis viroid, Columnea latent viroid, Potato spindle tuber viroid and Tomato chlorotic dwarf viroid. European Journal of Plant Pathology , 823-831. [doi:10.1007/s10658-004-2493-5]

To cite this report: Nielsen SL, Nicolaisen M, 2010. First report of Columnea latent viroid (CLVd)in Gloxinia gymnostoma, G. nematanthodes and G. purpurascens in a botanical garden in Denmark. New Disease Reports 22, 4. 